DOI: $10.17951 / \mathrm{m} \cdot 2019.4 .69-79$

\begin{tabular}{lcr}
\hline & ANNALES \\
& UNIVERSITATIS MARIAE CURIE-SKŁODOWSKA & \\
LUBLIN - POLONIA & \\
VOL. IV & SECTIO M & 2019 \\
\hline
\end{tabular}

\author{
Justyna Trubalska \\ University of Economics and Innovation in Lublin \\ justyna.trubalska@gmail.com \\ ORCID ID: http://orcid.org/0000-0001-6508-0580
}

\title{
The prospects for energy cooperation in the Visegrad Group
}

\section{Introduction}

For countries of a similar economic, political, cultural and social potential, regional collaboration is an interesting and desirable option. A sense of community and common objectives give rise to various forms of cooperation, from bilateral to multilateral, and from informal to formal ${ }^{1}$. One of the crucial factors to induce cooperation among countries is their geographical position. ${ }^{2}$. This was the case of the Visegrad Group (V4), established in the early 1990s as an informal regional group. On 15 February 1991, Lech Walesa, the President of Poland, Václav Havel, the President of Czechoslovakia, and József Antall, the Prime Minister of Hungary, signed a joint statement setting out the objectives and conditions of cooperation. The focus of the group's activities is on strengthening cooperation. They provide a platform for experience exchange for the development of common positions regarding issues relevant to the future of

\footnotetext{
1 H. Dumała, Theory and practice of international regions in international relations [Regiony międzynarodowe $w$ teorii i praktyce $w$ stosunkach międzynarodowych], [in:] Regions in international relations [Regiony w stosunkach międzynarodowych], eds. I. Topolski, H. Dumała, A. Dumała, Wydawnictwo Uniwersytetu Marii Curie Skłodowskiej, Lublin 2009, p. 15-17.

2 Ibidem, s. 17.
} 
the region and the $\mathrm{EU}^{3}$. Initially, the group's objectives did not take into account the energy policy and energy security issues. However, V4 was an instrument for the members to agree on common positions from the beginning. Over the years, their cooperation has expanded beyond the exchange of information and into interoperability with regard to culture, science and education into various areas of the economy, including energy. This particular cooperation saw a breakthrough on 24 February 2010 at the security energy summit, when the members signed a joint declaration.

The initiatives aimed at energy cooperation within the European Union indicate that countries which share conditions and purposes reap the most substantial benefits of the cooperation. This also applies to the strengthening of the energy security of the members. From this point of view, it is worth to analyse energy cooperation of the Visegrad Group: Poland, the Czech Republic, Hungary and Slovakia.

The main aim of this paper is to analyse the cooperation of the Visegrad Group in the field of energy. The author adopted a research hypothesis to be examined in the course of the study, stating that the energy policy of the Visegrad Group is correlated with the energy policy of the European Union. Successful energy policy of the Visegrad Group is thus contingent upon particular political decisions of the EU. It is, therefore, appropriate to answer the question whether the V4 countries can have an independent energy policy within the forum.

\section{Conditions for energy cooperation within the Visegrad Group}

Apart from their geographic proximity, history and identity, members of the Visegrad Group share many features in respect of energy policy and energy security. The energy indicators, analysed and juxtaposed with the data on the other Member States of the European Union, indicate that the energy policy of the countries in question depends on similar factors.

The primary determinant of the security of the Visegrad Group is the geopolitical situation of its countries, not only in respect of the energy sector. Indeed, this is the defining factor for their policy regarding infrastructure, as well as fuel import. Central European countries, notably, have both significant reserves of solid fuels and the potential for the development of renewable energy sources. This, first and foremost, translates into the energy mix of the Visegrad Group. Levels of primary energy production, although varying, are determined by the

3 Ministry of Foreign Affairs, https://msz.gov.pl/pl/polityka_zagraniczna/europa/grupa_wyszehradzka/, "Visegrad Group" ["Grupa Wyszehradzka"], accessed on 25 August 2019. 
production of energy from coal. Based on the data for 2016, the largest producer of primary energy is Poland with 66.4 Mtoe. The Czech Republic ranks next with 27.2 Mtoe, then Hungary with 11.4 Mtoe and Slovakia with 6.2 Mtoe. As it was noted above, coal had a dominant position in the energy balance throughout the period examined, respectively $78,4 \%, 58.5 \%, 12.9 \%$ and $7.3 \%{ }^{4}$. An analysis of the energy balance in the Visegrad Group should take into account the fact that Poland is the only country not to produce primary energy from primary nuclear sources. Slovakia has the advantage here over the other countries (62.3\%), whereas the share of nuclear energy in Hungary (36.6\%) and the Czech Republic $(23 \%)^{5}$ should be considered significant to the whole energy balance. At this point, it is also worth to present the percentage of the remaining energy carriers. The indicators vary as to the production of primary energy from oil and gas. Production of primary energy from crude oil amounts to $1.5 \%$ in Poland, $0.4 \%$ in the Czech Republic, $6.2 \%$ in Hungary and just $0.1 \%$ in Slovakia. The use of natural gas as a source of primary energy, in turn, adds up to $5.3 \%$ in Poland, $0.7 \%$ in the Czech Republic, $12.6 \%$ in Hungary and $1.2 \%$ in Slovakia ${ }^{6}$. These countries also show a steady increase in the use of renewable energy sources, amounting to $28.1 \%$ in Hungary, $25.9 \%$ in Slovakia, $15.8 \%$ in the Czech Republic and $13.6 \%$ in Poland ${ }^{7}$. The shares of particular energy carriers in the production of primary energy directly determine the energy policy and the interests of the State in this area of its operations. It is also important to note that the share of coal in the structure of energy balance for particular countries is declining in favour of liquid fuels and renewable energy sources. This results from the legal measures adopted, inter alia at the EU level (e.g. the climate and energy package). At the same time, the energy mix of the V4 countries encompasses crude oil and natural gas, which they produce only in small amounts and thus are forced to import. The main supplier of liquid raw material is the Russian Federation. Despite a small drop in its share of import, it is still a major supplier to this part of Europe. Upon analysis of selected energy indicators, it is possible to determine the energy dependency rate, particularly noteworthy for individual energy raw materials. With the year 2016 as the base for the analysis, data indicate that Poland and the Czech Republic have exhibited a negative energy dependency rate in the coal sector, amounting to -12 and $-0.9^{8}$ respectively. This means that

Energy, transport and environment indicators - 2018 Edition, European Union, Luxembourg 2018, p. 29.

Ibid., p. 29.

Ibid., p. 29.

Ibid., p. 29.

Ibid., p. 40. 
both these countries have the export ability for the raw material. The rates of Slovakia and Hungary, in turn, are at 83.3 and 34.5, respectively, which proves a high level of import dependency. Simultaneously, the countries analysed showed a similar energy dependency rate in respect of crude oil, which amounted to 92.8 for Poland, 97.2 for the Czech Republic, 91.8 for Slovakia and 89.3 for Hungary 9 There are only minor differences in the natural gas sector: 78.4 for Poland, 95.7 for the Czech Republic, 92.8 for Slovakia, and 78.9 for Hungary ${ }^{10}$.

Moreover, the change in the use structure of particular energy carriers poses a challenge for the countries in the region as to the development of energy infrastructure, both in terms of transmission and distribution. The investments in the energy transmission infrastructure in this part of Europe constitute a crucial element of the internal electricity and natural gas market of the European Union. As a consequence, the investments resulting in the integration with the European transmission system operators receive PCI status (Project of common interest). This group of investments comprise e.g. the international North-South transit corridor project. It is to connect the LNG terminal in Swinoujscie, the Baltic Pipe, the Czech Republic, Slovakia and Hungary with the LNG terminal in Croatia ${ }^{11}$.

To conclude this part of the analysis, it may be stated that the V4 countries have similar conditions as to energy policy and energy security and thus face similar challenges in the energy sector ${ }^{12}$. As a result, the indicated entities seek to define their energy security in terms of maintaining the balance of the energy carriers used and the flexibility in the supplier structure. Besides the ongoing investments, the Visegrad Group should continue to focus on expanding the transmission and distribution infrastructure, which would contribute to their energy security and empower this region of Europe in respect of energy infrastructure. Such an approach remains indispensable for the construction of an integrated energy market within both the Visegrad Group and the European Union. A firm and coherent stand of the Visegrad Group within the European Union may become one of the pillars of the energy policy of all the V4 countries and increase the effectiveness of its initiatives. Cooperation in the area of energy security in the region is of significance due to various standpoints among the

\footnotetext{
$9 \quad$ Ibid., s. 40.

10 Ibid., s. 40.

11 Cf. J. Trubalska, Trans-European energy infrastructure projects. The case of the northsouth gas corridor, "Humanities and Social Sciences", 2016, No. 1, p. 191-202.

12 E. Kużelewska, A. Bartnicki, The Visegrad Group - new challenges to security and cooperation prospects [Grupa wyszehradzka-nowe wyzwania bezpieczeństwa i perspektywy wspótpracy], "Yearbook of European Integration" ["Rocznik Integracji Europejskiej"], 2017, No. 11, p. 104.
} 
individual EU member states. Different risk perception and the conflict of interests among the "Old" Member States and "New" ones which joined the EU in 2004 (and later) generates inconsistencies in matters of energy policy. This gives rise to the need for developing cooperation mechanisms that would adapt to new variables of the international environment in a compatible and continuous manner. It is all the more crucial now that the Visegrad countries have sufficient potential and capacity for the implementation of joint initiatives.

\section{The evolution of energy cooperation within the Visegrad Group}

It was only after the Polish-Ukrainian-Russian crisis in $2009^{13}$ that energy cooperation within the Visegrad Group has become an object of interest. The development of mutual relations in the energy sector was further reinforced by similar positions of the V4 countries on extending the range of raw material suppliers beyond the East. This direction remains attractive for supplying the members of the so-called "Old EU" with natural gas and crude oil. The first Energy Summit was held on 24 February 2010 in Budapest, yielding a measurable effect in the form of the Declaration of the Budapest V4+ Energy Security Summit. The document identified five primary courses of action aimed at increasing regional energy security. First, it recognizes the need for expanding the sources and routes of energy supply to the countries concerned. Secondly, the heads of government of the Visegrad Group put forward the idea to build the transnational North-South Gas Corridor. The corridor was intended as a bridge between the Świnoujście LNG terminal in Poland with the Adria LNG terminal in Croatia. Third, implementing the above is to increase the efficiency of activities aimed at integrating energy markets. Fourth, due to similar conditions and the risks resulting from them, it is necessary to take measures that would allow for developing crisis management mechanisms within the Visegrad Group. Fifth, the V4 countries adopted a common position regarding the energy policy of the European Union ${ }^{14}$. The course of action taken by the heads of government contribute to ensuring regional energy security within the European Union. Furthermore, the V4 supported the Nabucco pipeline construction project. The South Stream project, however, received only partial support of the group as it

13 T Kubin, Visegrad Group - prospects for the further cooperation [Grupa Wyszehradzka - perspektywy dalszej wspótpracy], "Athenaeum - Polish Political Science Studies", 2014, No. 42, p. 31.

14 The Visegrad Group, http://www.visegradgroup.eu/2010/declaration-of-the, "Declaration of the Budapest V4+ Energy Security Summit", accessed 17 July 2019. 
competes with the former of the projects ${ }^{15}$. The reorientation of the countries' approach towards energy security as a regional value in response to regional challenges and threats is a vital step nevertheless. In words of Ernest Wyciszkiewicz, "the Budapest declaration's notable feature is that, in comparison with previous documents of this kind, it devotes much more space to the raising of EU financing for the proposed projects" ${ }^{16}$.

The energy cooperation within the Visegrad Group was continued during the subsequent summit on 25 January 2011 in Bratislava, when the Declaration of V4 Energy Ministers was adopted ${ }^{17}$. It confirmed the need to search for possibilities to diversify energy supplies in such a way that energy products come from at least two directions outside the European Union. In the long term, these activities are to reduce the Group's dependency on the import of supply from Russia. The Declaration also addressed the crude oil sector, it was namely deemed necessary to take initiatives to diversify the oil supplies beside the ongoing supply from the Druzhba oil pipeline ${ }^{18}$. The Summit confirmed the validity of the guidelines developed in the 2010 Declaration and outlined the due dates for the directions adopted therein. The North-South Energy Corridor has thus become a priority and was affirmed to be placed into operation before 2020 . The Declaration of 2011 also refers to the development of alternative solutions to ensure energy security of the V4 countries, primarily in respect of nuclear power cooperation ${ }^{19}$. It also seeks to strengthen cooperation in the development of clean coal technologies ${ }^{20}$.

Greater cooperation in the field of energy security was an element of the Polish agenda for its presidency in the Visegrad Group, which started on 1 July $2012^{21}$. The Senate adopted a resolution encouraging "the Government of the Republic of Poland to take decisive action so that the Visegrad Group may be-

\footnotetext{
15 E. Wyciszkiewicz, Energy Summit in Budapest, "Bulletin PISM", 2010, No. 38, p. 1.

16 Ibid., s. 2.

17 The Visegrad Group, http://www.visegradgroup.eu/2011/declaration-of-v4-energy, "Declaration of V4 Energy Ministers", accessed 17 July 2019.

18 According to preliminary assumptions of the Summit participants, the supply of crude oil will be diversified by increasing the capacity of the Ingolstadt-Kralupy-Litvinov (IKL) pipeline, the TAL (Trans-Alpin) pipeline and the Adria pipeline.

19 Cf. T. Klepner, The Visegrad Group cross-border cooperation to ensure border security [Wspótpraca transgraniczna państw Grupy Wyszehradzkiej na rzecz zapewnienia bezpieczenstwa granic], "Poliarchia", 2014, No. 2, p.108.

20 Declaration of V4 Energy Ministers...

21 Official Gazette of the Republic of Poland ["Monitor Polski"] of 2012, item 446, Resolution of the Senate of the Republic of Poland of 14 June 2012 on the assumption of the presidency of the Visegrad Group by the Republic of Poland on 1 July 2012.
} 
come an area of energy security"22. On 31 October 2012, the V4 energy (economy) ministers signed a Memorandum of Understanding on the integration of the V4 regional gas market. The Memorandum set out a timetable of actions leading to the Road Map towards a Regional V4 Gas Market to be adopted at the end of the Presidency. On 16 June 2013, the prime ministers V4 endorsed a document Road Map Toward a Regional Gas Market Among the V4 countries ${ }^{23}$. The document reaffirmed the need for continued work on the development of energy infrastructure in the region, with an investment on the north-south axis given a priority. It is interesting to note that the document defined the challenges the Visegrad Group faces, as well as its operational objectives. These include the need to overcome administrative barriers impeding the implementation of the Group's priority projects and funding issues, particularly given the new EU financial perspective under the Connecting Europe Facility Instrument. Another element that is substantial for integration is the reduction of trade barriers. These result predominantly from different regulatory systems, transfer rules and tariff schemes $^{24}$. One of the fortes of the Road Map is that it emphasizes the need for increased cooperation in integrating regional infrastructure. The document in question highlights that it is necessary to institutionalise the process of the V4 gas market regionalisation. A top-down approach was adopted, giving the V4 ministers of energy the leading role in shaping the energy policy and taking final decisions regarding the regional structures of the V4 market. The document establishes the V4 Forum for Gas Market Integration, "which shall provide political support and coordination among ministries, national regulatory authorities and also transmission system operators, and shall navigate the regulatory harmonisation with a goal to assist in the joint establishment of relevant Network Codes and in streamlining the cooperation as regards potential for the implementation of the final regional V4 market design" ${ }^{25}$. The document contains a cooperation schedule, outlining the details of putting into place the integration process and for increasing collaboration.

Energy cooperation within V4 involves establishing common positions in matters vital for the countries of the region. The countries "speak with one voice"

\footnotetext{
22 Ibid., s.

${ }_{23}$ The Visegrad Group, Http://www.visegradgroup.eu/documents/official-statements, "Road Map toward a Regional Gas Market among the V4 countries", accessed 10 August 2019.

$24 \quad$ Ibid., s. 3.

$25 \quad$ Ibid., op. cit., p. 5.
} 
e.g. in the field of nuclear power development, in the global negotiations on climate change, and the discussions regarding the form of energy policy after $2020^{26}$.

It should also be pointed out that the Visegrad Group is also taking measures aimed at developing mechanisms of energy crisis prevention and management. As noted above, common conditions prompt the V4 countries to develop a common definition of energy security. It is imperative for them to ensure the security of supply, which is why the prime ministers of the Visegrad Group issued the "Joint Statement of the Heads of Government of the Visegrad Group Countries"27. The document, signed on 19 June 2019 in Bratislava, further stresses the need to continue work on a common risk assessment, as well as to establish a joint course of action aimed at hazard prevention at the regional level. Its objective would be to increase the regional security of gas supply. The ministers postulate that the construction of the internal energy market be completed, particularly in respect to the missing energy infrastructure. The document also calls for reinforcing the EU legislation on the security of supply and the transparency of all gas agreements and safeguarding the confidentiality of commercially sensitive information. Another petition is that the legislation should be fully implemented and competitive and affordable energy prices ensured ${ }^{28}$. At any level, the steps requested by the $\mathrm{V} 4$ representatives are essential for the strategic energy interests of both the countries of the region and the entire European Union.

In the future, the actions of the Visegrad Group can facilitate a smooth implementation of energy legislation at the EU level. Regional cooperation will ultimately give rise to effective crisis management mechanisms. Its most significant effect, however, will be to directly strengthen the energy security of the countries of the region and, indirectly, the entire European Union.

\section{Conclusion}

The development of energy cooperation within the Visegrad Group is crucial for providing energy security in the region. However, improving the energy infrastructure would not be possible without financial support from the EU.

\footnotetext{
${ }^{26}$ More information at: The Visegrad Group, http://www.visegradgroup.eu/documents/ official-statements, "Executive summary of the Polish Presidency in the Visegrad Group, Visegrad July 2012-June 2013", accessed 20 June 2019, p.3.

${ }_{27}$ The Visegrad Group, http://www.visegradgroup.eu/calendar/2015/joint-statement-ofthe, "Joint Statement of the Heads of Government of the Visegrad Group Countries", accessed 29 August 2019.

${ }_{28}$ Ibid.
} 
The initial research hypothesis was that the energy policy of the Visegrad Group and the energy policy of the European Union are interdependent. This hypothesis has been confirmed throughout this paper. First and foremost, the European Union is the "driving force" in respect of financing the key infrastructure investments in the region. The countries cooperating in the Visegrad Group share numerous challenges and interests in the field examined here, but are dependent on external financing in the pursuit of their objectives. Although it should not be assumed that energy infrastructure investments would not be implemented without EU financial support at all, there is a high probability of significant delays. At the same time, the decisions of the Visegrad Group reinforce the EU energy security at subregional levels. This is essential for a strong and coherent gas market. Thanks to the cooperation of the V4 representatives, it is possible to eliminate transmission bottlenecks at the European level [1]. The interdependence claim is thus well-founded. The correlation of energy policies is reflected in the harmonisation process of legal and political solutions adopted by the EU.

Considering the construction of a single energy and natural gas market, as well as the energy union within the EU, the energy cooperation measures taken by the Members of the Visegrad Group should be perceived positively. Close relationships between the EU member states in the future, established for the event of a crisis such as disrupted supply of natural gas, imply the necessity of cooperation. Cooperation mechanisms and fostering the existing relationships will have a key impact on EU energy security in this part of Europe.

In the years to come, the Visegrad Group in its basic form, i.e. Poland, the Czech Republic, Hungary and Slovakia, will have the potential to lead the subregional cooperation in Central and Eastern Europe within its extended form of Visegrad Group Plus.

\section{Bibliography}

\section{Sources}

- Official Gazette of the Republic of Poland ["Monitor Polski"] of 2012, item 446, Resolution of the Senate of the Republic of Poland of 14 June 2012 on the assumption of the presidency of the Visegrad Group by the Republic of Poland on 1 July 2012.

- Energy, transport and environment indicators - 2018 Edition, European Union , Luxembourg 2018.

- The Visegrad Group, http://www.visegradgroup.eu/2010/declaration-of-the, "Declaration of the Budapest V4+ Energy Security Summit", accessed 17 July 2019.

- The Visegrad Group, http://www.visegradgroup.eu/2011/declaration-of-v4-energy, "Declaration of V4 Energy Ministers", accessed 17 July 2019. 
- The Visegrad Group, h://www.visegradgroup.eu/calendar/2015/joint-statement-ofthe, "Joint Statement of the Heads of Government of the Visegrad Group Countries", accessed 29 August 2019.

- The Visegrad Group, Http://www.visegradgroup.eu/documents/official-statements, "Road Map toward a Regional Gas Market among the V4 countries", accessed 10 August 2019.

- The Visegrad Group, Http://www.visegradgroup.eu/documents/official-statements, "Executive summary of the Polish Presidency in the Visegrad Group, Visegrad July 2012-June 2013", accessed 20 June 2019.

- The Ministry of Foreign Affairs, Https://msz.gov.pl/pl/polityka_zagraniczna/europa/ grupa_wyszehradzka/, "Visegrad Group”, accessed 25 August 2019.

- Wyciszkiewicz E., Energy Summit in Budapest, "Bulletin PISM", 2010, No. 38, p. 1.

\section{Literature}

- Dumała H., Theory and practice of international regions in international relations [Regiony międzynarodowe w teorii i praktyce w stosunkach międzynarodowych], [in:] Regions in international relations [Regiony w stosunkach międzynarodowych], eds. I. Topolski, H. Dumała, A. Dumała, Wydawnictwo Uniwersytetu Marii Curie Skłodowskiej, Lublin 2009

- Klepner T. The Visegrad Group cross-border cooperation to ensure border security [Wspótpraca transgraniczna państw Grupy Wyszehradzkiej na rzecz zapewnienia bezpieczenstwa granic], „Poliarchia”, 2014, No. 2

- Kubin, Visegrad Group - prospects for the further cooperation [Grupa Wyszehradzka - perspektywy dalszej wspótpracy], "Athenaeum - Polish Political Science Studies", 2014, No. 42

- Kużelewska E., Bartnicki A. The Visegrad Group - new challenges to security and cooperation prospects [Grupa wyszehradzka-nowe wyzwania bezpieczeństwa i perspektywy wspótpracy], "Yearbook of European Integration" ["Rocznik Integracji Europejskiej”], 2017, No. 11

- Trubalska J., EU energy infrastructure in the context of the internal energy market: The case of natural gas infrastructure in Central Europe [Infrastruktura energetyczna UE w kontekście budowy wewnętrznego rynku energii na przykładzie infrastruktury gazu ziemnego w Europie Srodkowej], (in:) Energy security in the EU internal energy market [Bezpieczeństwo energetyczne na wspólnym rynku energii UE], eds. S. Gędek, M. Ruszel, Wydawnictwo Rambler, Warszawa 2015.

- Trubalska J., Trans-European energy infrastructure projects. The case of the north-south gas corridor, "Humanities and Social Sciences", 2016, no. 1. 
Summary The main aim of this paper is to analyze the cooperation of the Visegrad Group in the field of energy. In accomplishing this, the author adopted the research hypothesis that the energy policy of the Visegrad Group is correlated with the energy policy of the European Union. Successful energy policy of the Visegrad Group is thus contingent upon particular political decisions of the EU.

Keywords: international organisations, energy policy, energy infrastructure, the European Union

\section{Perspektywy współpracy energetycznej w Grupie Wyszehradzkiej}

Streszczenie Głównym celem artykułu jest analiza współpracy energetycznej państw Grupy Wyszehradzkiej. Przyjęto hipotezę badawczą, która zostanie zweryfikowana w opracowaniu. Polityka energetyczna państw Grupy Wyszehradzkiej jest współzależna z polityką energetyczną Unii Europejskiej. Tym samym powodzenie prowadzenia skutecznej polityki energetycznej państw Grupy Wyszehradzkiej jest uzależnione od decyzji politycznych na forum UE.

Słowa kluczowe organizacje międzynarodowe, polityka energetyczna, infrastruktura energetyczna, Unia Europejska 